\title{
Anna Szafrańska
}

\section{Borderland as a space fostering the contracting of mixed marriages - the truth and myths}

\begin{abstract}
Globalization phenomena not only enhance cultural cognition but also foster establishing close relationships, which might be also legally confirmed. Today, many borders - like the Polish-Czech one - are "dematerialized" and exist more in the memory and awareness of people than in the physical sense. For the needs of the analyses, the category of borderland in its territorial sense was applied. Living in the borderland provides chances for establishing close interpersonal relations. What enhances the establishing of such relations in the case of the Polish-Czech borderland are the similarity of languages, common history and cultural closeness. This also fosters contracting mixed marriages. However, do close neighbourhood and similar social environments really make people seek contacts with neighbours? Does this enhance shaping a positive attitude to cultural diversity. The conducted analyses were aimed at familiarizing with the declarations of the examined university students from Poland and the Czech Republic concerning the way in which mixed marriages are perceived in their environment.
\end{abstract}

Keywords: Polish-Czech borderland, mixed marriages, students

$* * *$

Globalization phenomena not only enhance cultural cognition but also foster establishing close relationships, which might be also legally confirmed. The easiness of moving around, tourist curiosity, searching for information about unknown places in the world, or mobility imposed by work cause that one meets people of other nationalities or representatives of other cultural circles. Moreover, media show with growing frequency or even promote the models of relationships which not long ago were considered exotic, very rare, different. In Poland, many programmes ${ }^{1}$ show foreigners as "friendly Others",

1 One of the most popular programmes was "Europa da się lubić [Europe is likeable]", which had the highest popularity ratings. Its heroes, who became the favourites of Poles almost overnight, largely contributed to the interest in the countries from which they came, but also showed that national stereotypes, so widely present in the 
interested in our country, settling down and raising families here. As a result, contemporary mixed marriages do not face such amazement and increasingly rarely result in rejection or stigmatization.

Currently, many borders - like the Polish-Czech one - are "dematerialized" and exist more in the memory and awareness of people than in the physical sense. Borderland is a category explored by many scientific disciplines. It is an object of numerous theoretical concepts in philosophy, economy, political studies, sociology or pedagogy. A borderland is a territory situated between two state (or regional) areas, characterized by ethnic or national migration resulting from the location in spatial closeness (Kłoskowska, 1996, p. 125).

Therefore, it can be treated as:

- physical territory - an effect of the indicating (in a certain space) of a border between states or nations;

- social space characterized by strong cultural diversity of both the material and non-material world. It refers to such spheres as tradition, religion, historical memory or the awareness of national belonging.

In a broader, interdisciplinary perspective, borderland was discussed by L. Witkowski, who made a philosophical-aesthetic reinterpretation of M. Bakhtin's concept. In his concept, Witkowski takes into regard four aspects of (the understanding of) ontology concerning "being between": borderland understood as a space, territory; high saturation of interactivity; detailed specification in the context of differences and similarities (of relations); and the creation (due to participants' ambivalent status) of the cultural situation, subjects or descriptive categories (Witkowski, 1991).

For the needs of the presented analyses, the category of borderland in its territorial sense has been applied. Forms of coexistence are shaped through being next to - closeness to each other and mutual contacts (Sadowski, 2008). The research analysed in this study was done among academic youth - students living in the borderland space of Poland and Czech Republic. The young currently living in the Polish-Czech borderland are a new generation, different than their earlier peers. This specificity and unlikeness has its sources in the sociocultural, political and economic situation of Poland, Europe and the world, which also constitutes an important reference point (Ogrodzka-Mazur, 2013, pp. 106-127). Life in the borderland provides a chance for establishing close interpersonal relations. In the case of the Polish-Czech

Polish culture, were not always confirmed. Steffen Möller, a German, can serve as an example. 
borderland, the linguistic similarity, often commonly shared history, and cultural closeness are the factors that enhance close relationships. According to A. Sadowski, the borderland situation means some particular phenomena of a mass and permanent flow (permeating) through cross-cultural borders of people, their cultural models, values, along with intense activities aimed at maintaining or developing these contacts by the neighbouring communities, their institutions and particular inhabitants (2008, p. 23). Yet, do the close neighbourhood, similar sociocultural determinants and linguistic similarity really make one seek a contact with the neighbours, enter close relations and facilitate nationally mixed relationships? My earlier studies among teachers often do not confirm this (Szafrańska 2017, 2019). Therefore, it seemed interesting to me how the issue of mixed marriages is viewed by young adults inhabiting the Polish-Czech borderland.

\section{Methodological foundations of the research}

The processes of transformations in Poland, the Czech Republic and other countries of Central and Eastern Europe encouraged (in 2018) undertaking comparative team studies on cultural identity and education of young adults. The research comprised 330 university students - 164 in Poland (Cieszyn) and 166 in the Czech Republic (Ostrava). The sample was representative for pedagogy students educated in the University of Silesia and the University of Ostrava. In the academic year 2017/18, 518 students undertook both fulltime and part-time studies in the course pedagogy at the Faculty of Ethnology and Education of the University of Silesia. The required representative sample size was specified with the help of the sample size calculator. For the size of population, the following was assumed: fraction size 0.5 , confidence interval 85\%, maximum error 0.5 (the $9 \%$ error is still acceptable for concluding in social sciences, the estimation results are valid). As Dorota WęziakBiałowolska claims, concluding with the $15 \%$ error constitutes the lower limit for not accepting (2013). The representative size for Polish students was 148 people. In the academic year 2017/2018, 2240 students were educated at the Faculty of Education in Ostrava. The research was conducted with the use of a questionnaire survey sent to students' by e-mail. The sample consisted of 166 respondents who had fulfilled the questionnaire. These were full-time and part-time students educated in various pedagogical courses both with and without teaching qualifications. The sample was representative with the assumption of the maximal error of $8 \%$. 
The nationality composition was slightly different. This results from the fact that 2 respondents in Poland indicated their Czech nationality (students from Zaolzie) and 1 declared another (Ukrainian) nationality, whereas in the Czech Republic 2 students declared a different nationality than the Czech one. Altogether, 161 students declared Polish nationality (48.9\%), 165 Czech nationality (50.2\%), and $3(0.9 \%)$ another nationality (cf. Figure 1 and 2). One person did not declare nationality at all.

The respondents were mostly aged 19-22 - such age was indicated by 170 students (51.7\%). A similar number of respondents were aged 23-26 $80(24.3 \%)$ and 27 years and more - 79 (24\%). Among students from Poland, there are much fewer people belonging to the oldest age group.

The analyses made for the needs of this article ${ }^{2}$ were aimed at familiarization with the declarations of the respondents from Poland and the Czech Republic pertaining to mixed marriages. The answers were sought to the following questions: What are respondents' opinions on mixed marriages? What difficulties do they notice in their functioning? (How) Does the level of significance attributed to religion and its issues determine the attitude of respondents to the problems resulting from the functioning in mixed marriages?

\section{Mixed marriages in the declarations of Polish and Czech students - a research analysis}

In expert literature, mixed marriages are distinguished in regard to different qualities of partners, such as: nationality, home country, ethnic origin, race, religion. In the case of marriages involving people of different nationality or citizens of different states, the notion of binational or trans-frontier marriages is often used (Rajkiewicz 2009, p. 170). Another term is applied by M. Jodłowska-Herudzińska - intercultural mixed marriages. The author emphasizes that a specific situation takes place in such marriages - a "meeting" of partners who represent different cultures and decide to get married, which means a shared life, mutual support and bringing up children (2001,

2 Extensive analyses of the studies were presented by the Polish-Czech team in the monograph: Ogrodzka-Mazur, E., Szafrańska, A., Malach, J. and Chmura, M. 2021. Cultural identity and education of learning young adults in selected countries of East-Central Europe. A Polish-Czech comparative study. Göttingen: Vandenhoeck \& Ruprecht Verlage. 
pp. 279-289). This "meeting" or the widely described within intercultural education clash of cultures is a factor that substantially determines the way in which mixed marriages function. Homogamy means the marital union between people of similar ethnic origin, nationality, religion, education, or socio-economic status. The bigger the similarity is, the bigger homogamy (as an indicator of the integrity of the category and the sharpness of social barriers) takes place (Brzozowska 2015, p. 9). It is assumed that the degree of partners' similarity (especially as regards cultural qualities) determines marital satisfaction. Therefore, as a rule - mixed marriages are more difficult relationships (Jodłowska-Herudzińska 2002, p. 174).

The question was asked how mixed marriages were perceived in their environment (cf. Table 1). In general, in most of the answers 173 respondents (over 52\%) indicated that the perception of such marriages was good. The most frequent answer was "positively" - 132 respondents (39.6\%). The second largest group indicated "indifferently" - 112 people (33.6\%). The answer "very positively" was chosen by 41 students (12.3\%). A slightly smaller group of 35 respondents $(10.5 \%)$ claimed that mixed marriages were perceived negatively and 7 respondents $(2.1 \%)$ - very negatively.

Table 1. The perception of mixed marriages in the respondents' environment

\begin{tabular}{|l|r|c|}
\hline & Number & $\%$ \\
\hline Very positively & 41 & 12.3 \\
\hline Positively & 132 & 39.6 \\
\hline Indifferently & 112 & 33.6 \\
\hline Negatively & 35 & 10.5 \\
\hline Very negatively & 7 & 2.1 \\
\hline No answer & 6 & \\
\hline Total & 327 & 98.2 \\
\hline
\end{tabular}

Source: own research $\mathrm{N}=333$.

There are slight differences in the way mixed marriages are perceived by Polish and Czech students. The largest group of respondents declared positive perception of such marriages in their environment. Yet, much more frequently, these were Czech students (72; Poles - 59). A neutral attitude to mixed marriages was more often declared by Poles (60; Czechs - 51). "Very positively" was indicated more frequently by students from the Czech Republic (22), as well as the answer "negatively" (19; 15 - Poles). The answer "very negatively" was declared by 5 Polish students and 2 Czech ones (Table 2). 
Table 2. The perception of mixed marriages in the respondents' environment with a distinction between students learning in Poland and the Czech Republic

\begin{tabular}{|l|c|c|c|c|c|c|}
\hline & Very positively & Positively & Indifferently & Negatively & Very negatively & Total \\
\hline Students from PL & 19 & 59 & 60 & 15 & 5 & 158 \\
\hline Students from CZ & 22 & 72 & 51 & 19 & 2 & 166 \\
\hline Total & 41 & 131 & 111 & 34 & 7 & 324 \\
\hline
\end{tabular}

Source: own research $\mathrm{N}=324$.

Another issue investigated by me was how the respondents view the difficulties/problems which a mixed marriage can face. The question could be answered with a choice of six answers or one could write one's own answer. In the provided answers, the problems were taken into account which refer to functioning in various social groups and relationships, as well as the problems related to various fields - from educational problems with children, through barriers in communication, to professional issues.

The most frequent answer was intolerance of native residents (33.3\%) the people from the same nationality group. This is surprising as it indicates lack of acceptance experienced by people in such a relationship in their own cultural group. Thus, maybe due to their own experiences, students tend to attribute hermeticity to these groups, as well as the blocking of others who might want to join that group by formal marriage. The second largest group of respondents (25.8\%) indicated assimilation problems in the residence place and social isolation. In this case, the respondents focus on a problem which is not limited only to one cultural circle $-1 / 4$ of the respondents stress that mixed marriages may experience social isolation. This seems dangerous as it leads to the marginalization of such families, which poses a particular threat in the situation of children raised in a mixed family. For $17.4 \%$ of students, the most important problems were those related to language communication. While the two previous groups of answers result from the social attitude, this case involves barriers associated with language competences of people deciding to change e.g. their residence place and, as a consequence, the necessity to acquire another language. The other answers were much less frequent. The difficulties associated with finding a job were indicated by $6.9 \%, 6 \%$ of the respondents pointed to the lack of acceptance by the married couple's family/families. The latter answer is of particular significance, especially in the context of a large number of people declaring that the native inhabitants' intolerance is a problem. The examined students rarely notice that this intolerance pertains to members of the nearest family. What seems equally optimistic is that the respondents rarely (only 4.2\%) notice that problems concern 
the bringing up of children. The same number of students indicated "others", which involved such answers as "none" (students from the Czech Republic) and general answers like "religious and cultural differences" (students from Poland). The detailed data are presented in Table 3.

Table 3. The difficulties which mixed marriages can face as indicated by university students from Poland and the Czech Republic

\begin{tabular}{|l|c|c|}
\hline \multicolumn{1}{|c|}{ Respondents' answers } & Number & $\%$ \\
\hline Intolerance of native residents & 111 & 33.3 \\
\hline Assimilation problems & 86 & 25.8 \\
\hline Difficulties associated with finding a job & 23 & 6.9 \\
\hline Problems with related to language communication & 58 & 17.4 \\
\hline No acceptance from the family & 20 & 6.0 \\
\hline Problems with raising children & 14 & 4.2 \\
\hline No answer & 7 & \\
\hline Others & 14 & 4.2 \\
\hline No data & & 2.1 \\
\hline Total & 333 & 100.0 \\
\hline
\end{tabular}

Source: own research

There is a statistically significant dependence with low association strength between the place of studying (PL/CR) and students' answers for $\mathrm{p}=0.004<0.05$ Cramer's $\mathrm{V}=0.242$. The students from Ostrava more often claimed that mixed marriages had assimilation difficulties in their place of residence due to social isolation and communication problems. The students from Poland more often stated that mixed marriages face intolerance from native residents. The detailed data are comprised in Table 4.

Table 4. The surveyed students' opinions on the problems which mixed marriages might face in regard to the place of studying

\begin{tabular}{|l|c|c|c|c|c|c|c|c|}
\hline & intolerance... & $\begin{array}{c}\text { assimilation } \\
\text { problems }\end{array}$ & $\begin{array}{c}\text { difficulties } \\
\text { with ... }\end{array}$ & $\begin{array}{c}\text { commu- } \\
\text { nication } \\
\text { problems }\end{array}$ & $\begin{array}{c}\text { no } \\
\text { acceptance }\end{array}$ & $\begin{array}{c}\text { problems } \\
\text { with } \\
\text { raising... }\end{array}$ & others & Total \\
\hline \multirow{2}{*}{ PL } & 68 & 39 & 7 & 23 & 11 & 7 & 2 & 157 \\
\cline { 2 - 10 } & $43.3 \%$ & $24.8 \%$ & $4.5 \%$ & $14.6 \%$ & $7.0 \%$ & $4.5 \%$ & $1.3 \%$ & $100.0 \%$ \\
\hline \multirow{2}{*}{$\mathrm{CZ}$} & 42 & 46 & 16 & 35 & 9 & 7 & 11 & 166 \\
\hline Number & $25.3 \%$ & $27.7 \%$ & $9.6 \%$ & $21.1 \%$ & $5.4 \%$ & $4.2 \%$ & $6.6 \%$ & $100.0 \%$ \\
\hline$\%$ & 110 & 85 & 23 & 58 & 20 & 14 & 13 & 323 \\
\hline
\end{tabular}

$\mathrm{X}^{2}=18.921 ; \mathrm{df}=6$; for $\mathrm{p}=0.004<0.05$ Cramer's $\mathrm{V}=0.242$

Source: own research. 
Another item to investigate was whether and how the respondents' attitude to religion and religious issues determines the perception of problems experienced by mixed marriages. Those who are familiar with the specificity of the importance of religion for Poles and Czechs know that whereas this is an issue of particular significance for Poles (though this is changing in the case of youth), Czechs are considered to be one of the most secularized European nations. The respondents were to indicate on a four degree scale (from very important to quite unimportant) the significance of religion and religious issues in their life. The $\chi^{2}$ test indicated statistical significance $(p=0.000<0.05)$ of the relation between the significance of religion and religious issues in one's life and the place of studies. Cramer V indicated a correlation with high association strength at the level of 0.543 . Substantially more often, students from Poland regard religious issues as very important (82.4\%) and important (70.5\%). The respondents studying at the University of Ostrava much more frequently treat them as unimportant $(74.5 \%)$ or quite unimportant (82.5\%). The details are presented in Table 5.

Table 5. Respondents' attitude to religion and its issues in regard to the place of studying

\begin{tabular}{|l|l|c|c|c|}
\hline \multicolumn{2}{|c|}{} & Students from Poland & Students from the Czech Republic & Total \\
\hline \multirow{2}{*}{ Very important } & Number & 61 & 13 & 74 \\
\cline { 2 - 5 } & $\%$ & $82.4 \%$ & $17.6 \%$ & $100.0 \%$ \\
\hline \multirow{2}{*}{ Important } & Number & 67 & 28 & 95 \\
\cline { 2 - 5 } & $\%$ & $70.5 \%$ & $29.5 \%$ & $100.0 \%$ \\
\hline \multirow{2}{*}{ Unimportant } & Number & 25 & 73 & 98 \\
\cline { 2 - 5 } & $\%$ & $25.5 \%$ & $74.5 \%$ & $100.0 \%$ \\
\hline \multirow{2}{*}{ Quite unimportant } & Number & 11 & 52 & 63 \\
\cline { 2 - 5 } & $\%$ & $17.5 \%$ & $82.5 \%$ & 330 \\
\hline \multirow{2}{*}{ Total } & Number & 164 & 166 & $100.0 \%$ \\
\cline { 2 - 5 } & $\%$ & $49.7 \%$ & $50.3 \%$ & \\
\hline
\end{tabular}

$\mathrm{N}$ valid observations: 330

$\mathrm{X}^{2}=97.33 ; \mathrm{df}=3$; for $\mathrm{p}=0.000<0.05$ Cramer`s $\mathrm{V}=0.543$ Much less often $(18.2 \%)$

Source: own research.

The people who consider religion and its issues as very important in their life most frequently $(40.8 \%)$ regard the intolerance of native residents as the biggest problem that mixed marriages can face. Much less often (28.2\%), they indicated the problems related to assimilation in the residence place / social isolation. They very rarely (2.8\%) pointed to the difficulties in finding work.

Similar declarations appeared in the group of respondents who declared that religious issues are important to them. Most frequently (though more 
rarely than in the previous group), they indicated problems associated with native inhabitants' intolerance of mixed marriages (35.9\%) and problems with assimilation in the residence place (22.8\%). The representstives of this group most often among all respondents indicated lack of acceptance on the part of the partners' family/families (8.7\%). The detailed data are presented in Table 6.

Table 6. Respondents' attitude to religion and its issues versus their opinion on problems experienced by mixed marriages

\begin{tabular}{|l|l|c|c|c|c|c|c|c|c|}
\hline \multicolumn{2}{|c|}{$\begin{array}{c}\text { Religion and its issues } \\
\text { in my life are regarded as: }\end{array}$} & 1 & 2 & 3 & 4 & 5 & 6 & 7 & total \\
\hline \multirow{2}{*}{ very important } & Number & 29 & 20 & 2 & 11 & 4 & 4 & 1 & 71 \\
\cline { 2 - 12 } & $\%$ & $40.8 \%$ & $28.2 \%$ & $2.8 \%$ & $15.5 \%$ & $5.6 \%$ & $5.6 \%$ & $1.4 \%$ & $100.0 \%$ \\
\hline \multirow{2}{*}{ important } & Number & 33 & 21 & 4 & 16 & 8 & 6 & 4 & 92 \\
\cline { 2 - 11 } & $\%$ & $35.9 \%$ & $22.8 \%$ & $4.3 \%$ & $17.4 \%$ & $8.7 \%$ & $6.5 \%$ & $4.3 \%$ & $100.0 \%$ \\
\hline \multirow{2}{*}{ unimportant } & Number & 34 & 23 & 11 & 20 & 4 & 1 & 4 & 97 \\
\hline \multirow{2}{*}{ quite unimportant } & $\%$ & $35.1 \%$ & $23.7 \%$ & $11.3 \%$ & $20.6 \%$ & $4.1 \%$ & $1.0 \%$ & $4.1 \%$ & $100.0 \%$ \\
\hline & Number & 14 & 21 & 6 & 11 & 4 & 3 & 4 & 63 \\
\hline & Number & $22.2 \%$ & $33.3 \%$ & $9.5 \%$ & $17.5 \%$ & $6.3 \%$ & $4.8 \%$ & $6.3 \%$ & $100.0 \%$ \\
\hline & $\%$ & $34.1 \%$ & $26.3 \%$ & $7.1 \%$ & $18.0 \%$ & $6.2 \%$ & $4.3 \%$ & $4.0 \%$ & $100.0 \%$ \\
\hline
\end{tabular}

Legend: 1 - intolerance... 2 - assimilation problems; 3 - difficulties with...; 4 - communication problems; 5 - no acceptance; 6 - problems with raising...; 7 - others

In the group of respondents who declared that religious issues are unimportant in their life, the most frequently chosen answers were also those which concerned intolerance of native residents (35.1\%) and assimilation in the residence place (23.7\%). In this group, there was the biggest number of respondents who pointed to problems with communication (20.6\%) and finding a job (11.3\%).

The last (and the smallest) group were the respondents who declared that religious issues are unimportant to them. The composition of answers is different here as the biggest number of people here indicated assimilation problems (33.3\%).

\section{Conclusions}

The Polish-Czech borderland is a specific space, especially in the area of the euroregions of Cieszyn Silesia and Beskidy. As a result of a long-term process of the diffusion and overlapping of different cultures, a specific type of com- 
munity, which represents various cultural (also language-related) patterns, has come into being. There are many mixed marriages in the borderland. This is enhanced by the situation on the Czech side, where a large Polish community lives. However, this is not a homogeneous group. Some members cherish Polish culture and traditions, which is facilitated by the network of schools in Zaolzie educating in Polish. Some people of Polish origin have undergone assimilation, which has often resulted from establishing mixed marriages and bringing up children in the culture of the dominating (Czech) group. The situation on the Polish side, where there are much fewer such marriages, is slightly different.

The examined students are most often of the opinion that mixed marriages are viewed positively in their environment, almost $1 / 3$ (33.6\%) emphasize that such relationships are treated with indifference and $12.6 \%$ that the environment's attitude to such marriages is negative. Slightly more frequently, Poles point to indifference which mixed marriages face in their environment, whereas students from the Czech Republic more often indicate a positive image of mixed marriages in their circles. Thus, it seems surprising that while pointing to problems which mixed marriages have to handle, the respondents indicate most often the lack of acceptance by their own cultural group and the situations related to social isolation. Unfortunately, the applied research methodology has not made it possible to find out how this difference in declarations came into being - the difference between the general social perception of mixed marriages and the noticing of problems which, as the analyses have revealed, exist mostly in the environment. This is particularly visible in the declarations of the respondents who treat religion and religious issues as very important or important. In the studies, the problems related to employment and communication barriers were indicated much less frequently.

\section{Bibliography}

Brzozowska, A. 2015. Dobór matżeński i integracja imigrantów w matżeństwach mieszanych - stan badań. Ośrodek Badań nad Migracjami: http:// www.migracje.uw.edu.pl/wp-content/uploads/2016/06/WP811392.pdf (9.03.2021).

Jodłowska-Herudzińska, M. 2001. Partnerstwo w międzykulturowych małżeństwach mieszanych. In: Tyszka, Z. ed. Rodzina w czasach szybkich przemian. Roczniki Socjologii Rodziny. XIII, pp. 279-288. 
Jodłowska-Herudzińska, M. 2002. Kwestie doboru małżeńskiego w międzykulturowych małżeństwach mieszanych. Roczniki Socjologii Rodziny. XIV, pp. 173-189.

Lewowicki, T., Szczurek-Boruta, A. and Szafrańska, A. 2017. Sfery życia duchowego dzieci, mtodzieży i dorostych - studium z pogranicza polsko-czeskiego. O nauczycielach, ich spostrzeganiu świata społecznego i aktywności. Vol. 4. Cieszyn - Toruń: Wydział Etnologii i Nauk o Edukacji Uniwersytetu Śląskiego, Wydawnictwo Adam Marszałek.

Ogrodzka-Mazur, E. 2013. (Nie)obecność patriotyzmu w świadomości aksjologicznej młodego pokolenia Polaków - „przesuwanie się horyzontu aksjologicznego" czy kryzys w wartościowaniu? In: Nikitorowicz, J. ed. Patriotyzm i nacjonalizm. Ku jakiej tożsamości kulturowej? Kraków: Oficyna Wydawnicza "Impuls", pp. 106-127.

Ogrodzka-Mazur, E., Szafrańska, A., Malach, J. and Chmura, M. 2021. The cultural identity and education of university students in selected East-Central countries. A Polish-Czech comparative study. Göttingen: Vandenhoeck \& Ruprecht Verlage.

Rajkiewicz A. 2009. Polskie małżeństwa binacjonalne. Materiały. Biuletyn Rzecznika Praw Obywatelskich Materiaty. 66, pp. 170-176.

Sadowski, A. 2008. Pogranicze - pograniczność - tożsamość pogranicza. In: Bojar, H., Wojakowski, D. and Sadowski, A. eds. Polskie granice i pogranicza. Nowe problemy i interpretacje. Pogranicze. Studia Społeczne. XIV, pp. 17-30.

Szafrańska, A. 2019. Nauczyciele z pogranicza polsko-czeskiego o swoich sąsiadach. Pedagogika Społeczna. 2, pp. 149-162.

Witkowski, L. 1991. Uniwersalizm pogranicza. O semiotyce kultury Michała Bachtina w kontekście edukacji. Toruń: Wydawnictwo Adam Marszałek. Witkowski, L. 1995. Ambiwalencje tożsamości z pogranicza kulturowego. In: Urlińska, M.M. ed. Edukacja a tożsamość etniczna. Toruń: UMK, pp. 11-23 . 